IRSH 62 (20I7), Special Issue, pp. I9I-2 I 6 doi: I0.10I7/S00208590 I 700059I (C) 20 I 8 Internationaal Instituut voor Sociale Geschiedenis

\title{
The Local and the Global: Neighborhoods, Workers and Associations in São Paulo (1945-1964)
}

\author{
PAULO FONTES \\ School of Social Sciences of the Fundação Getulio Vargas \\ (CPDOC/FGV), Praia de Botafogo, I90 - sala I422, I4 Andar \\ Botafogo, Rio de Janeiro \\ RJ, $22250-900$, Brazil \\ E-mail: paulo.fontes@fgv.br
}

AвSTRACT: This article aims to analyze residents' associations organized around specific working-class neighborhoods in São Paulo between the end of World War II and the Brazilian Military coup in 1964. It examines, in particular, the connections between neighborhood associations and labor union struggles. Based on the strong social networks and informal relationships created by workers, organizations like the Neighborhood Friends Societies (Sociedades Amigos de Bairro) were fundamental to the construction of political communities that had a powerful impact on electoral processes and on the formation of the state at the local level. Likewise, this article will show how, during that period, identities at the neighborhood level frequently developed in dialogue with processes of class formation, staking claim to a language of rights associated with the condition of being a worker and, simultaneously, a citizen. Finally, the piece suggests how analyses with such a localized scope, like those focused on specific working-class neighborhoods can intervene in debates concerning Global Labor History.

On 27 January 1954, Heitor Brugners, the director of the Friends of Vila Palmeira Society in a neighborhood to the north of the city of São Paulo, wrote a letter requesting that Jânio Quadros, São Paulo’s mayor who would later be elected president of Brazil, intervene in an ongoing matter with São Paulo Light and Power, the Canadian company that held the concession for the city's public lighting. Brugners hoped that, with the mayor's help, the powerful concessionaire could be convinced to install streetlights in his neighborhood, in the far outskirts of the city. ${ }^{2}$ In June of that year, residents of Vila Independência in the town of Ipiranga likewise directed a petition to

I. Paulo Fontes holds a research fellowship Pesquisador Bolsista Produtividade by the Conselho Nacional de Desenvolvimento Científico e Tecnológico (CNPq). I thank the participants in the two workshops carried out to develop this Special Issue. In particular, I would like to thank Adalberto Paz and David Mayer for their comments and suggestions.

2. Processo 07144I/1954, Secretaria Municipal de Gestão (Prefeitura de São Paulo) - Divisão do Arquivo Municipal de Processos [hereafter, DGDP-2], Secretaria Municipal de Planejamento, Orçamento e Gestão [hereafter, SMPOG]). 
their city's mayor by way of their local Neighborhood Friends Society (Sociedade Amigos de Bairro). This petition, like their counterparts in Vila Palmeira, asked the mayor to intervene with The São Paulo Light and Power Company, to request the installation of an external energy connection to power the existing streetlamps in their district" of "approximately 30.000 inhabitants", to achieve "JUSTICE" in "finding a solution to one of the most sensitive problems, since a large number of workers, young women and men, suffer all types of danger, from accidents to assaults". ${ }^{4}$ And the president of the Vila Ipojuca Friends Society, in São Paulo's Lapa district, claiming to speak on behalf of residents, made a similar plea for public street lighting in his area, in a petition to the mayor dated I September I954, which also included several other requests. ${ }^{5}$

These types of letters, requests, and petitions addressed to public authorities in São Paulo were common in the post-World War II period. In general, these communications were sent via so-called Neighborhood Friends Societies (Sociedades Amigos de Bairro, or SABs), a form of association for local residents that emerged and proliferated in the city from the late I940s. From the end of the Estado Novo dictatorship, under Getúlio Vargas, in 1945 , until a military coup in 1964 instated a dictatorship that would last for more than twenty years, Brazil lived through its first experience of mass democracy. In addition to regular elections, workers and popular sectors in general managed to significantly expand both their level of self-organization and their ability to make claims vis-à-vis the state, thus increasing their weight and say in public affairs.

In this context, the tendency to form popular associations based on neighborhoods (and the specific territorial space they defined) gained strength and came to characterize the history of social movements and political life in São Paulo and its surrounding industrial towns. Tenants' organizations, residents' associations, Neighborhood Friends Societies, favelas organizations (informal housing settlements), sporting and recreational clubs with strong local ties, etc. made up the exceedingly diversified and complex mosaic of the associative lives of urban workers, which had political and social repercussions that, at many points in the city's twentieth-century history, transcended the local level. This dynamic was fundamental to the city's class formation process, and it frequently developed in tandem with the more "classic" workers' movement defined by unions and political parties.

3. The basic administrative level in Brazil, both in the period analyzed in this article and today, is the municipality (municipio), each of which has its own government bodies. Municipalities may introduce subdivisions, such as districts, neighborhoods, or villages, yet these exist for purely administrative reasons, are often vaguely defined, and have no legal effect or political autonomy. 4. Processo I 29598/1954, DGDP-2, SMPOG. Capitalization as in original.

5. See Processos I33526/1954 to I33524/1954, DGDP-2, SMPOG. 


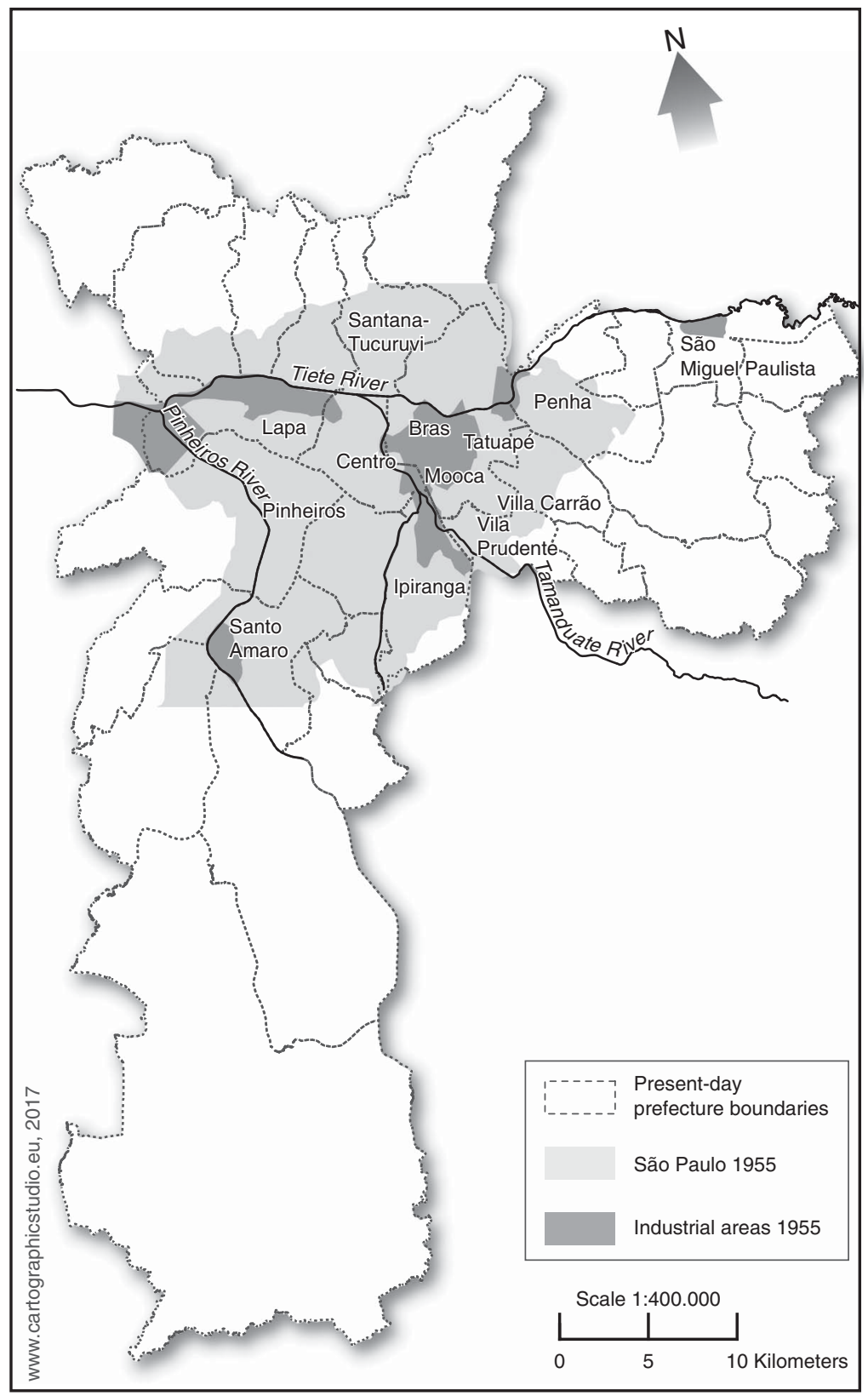

Figure I. São Paulo's industrial areas in 1955. 
Between 1940 and 1970, São Paulo and the cities that surrounded it (in what would come to be known as the metropolitan region of "Greater" São Paulo) experienced an industrial boom and an impressive urban and population expansion (a process that would continue in the four decades to follow), transforming São Paulo into one of the largest cities in the world. Two characteristics of this vertiginous, dual process of industrialization combined with urbanization stand out. First, São Paulo's twentieth-century urbanization process is characterized by its tendency to segregate by class, marked as it was by the intense and continuous expulsion of the poorer classes from the central regions to the peripheries of the city. This "peripheral pattern of urban growth", to use a term well-established in the specialized literature, marked urban development in the post-war period: ${ }^{6}$ A large part of the working population came to live in peripheral areas that were increasingly removed from the urban center and increasingly bereft of urban resources, widening the geographical, social, and cultural distances between the city's different social classes. The magnitude of the wave of immigration during that period further accelerated the creation of neighborhoods in the peripheries, especially in the eastern and southern regions of the city. A greater distance between one's home and work (although a sizeable portion of the workers found jobs in these peripheral neighborhoods), a growing dependency on public transportation, in particular buses, and individually owned houses constructed by their residents in peripheral lots are some of the most distinctive characteristics of the daily experiences of São Paulo's working class during this new era. A second feature of the history of urbanization and industrialization in São Paulo concerns the importance of these neighborhoods as spaces of conviviality and sociability, especially for the popular classes. ${ }^{7}$ They were fundamental spaces for the formation of social networks and common experiences - in both the work sphere and residential life. A place of residence, leisure, and labor, one's neighborhood also contained the entire spectrum of personal relationships with family members, friends, and neighbors, equipping workers with knowledge and personal contacts that were essential to quotidian life. Unsurprisingly, Jorge Wilheim, a famous Brazilian urbanist concerned with urban planning between the I960s and the I980s, emphasized the strong local identities that centered on neighborhoods: For him, the neighborhood

6. For studies using the notion of "peripheral patters of urban growth" in the case of São Paulo, see, for instance, Lucio Kowarick (ed.), Social Struggles and the City: The Case of São Paulo (New York, I994); Teresa Caldeira, City of Walls: Crime, Segregation, and Citizenship in São Paulo (Oakland, CA, 2000).

7. Such characteristics are in no way exclusive to São Paulo. In fact, it appears to be a common feature of large Latin American metropolises that have gone through processes of rapid industrialization and urbanization, such as Buenos Aires, Mexico City, and Lima, among others, making them appropriate for applying translocal, comparative analyses. 
was "the urban unit, the most legitimate representation of the spatiality" of the population of the city of São Paulo. ${ }^{8}$ Even today, the idea of a city historically forged by various local identities seems to have endured. The French anthropologist Oliver Mongin, for instance, recently stated that São Paulo is still "made up of multiple and varied neighborhoods, in which we feel a strong sense of autonomy". 9 In the decades following World War II, the experiences of residents of the neighborhoods in São Paulo's, especially, in the expanding peripheries, were powerfully marked by a general dearth of urban infrastructure. But disillusionment with the promises of urban progress and the growing perception that inequalities and exploitation also pervade the urban fabric provoked a burst of associative activity, for which the neighborhoods would provide a common thread and a central identity.

This article seeks to analyze these residents' associations organized around specific neighborhoods between the end of World War II and the coup in I964. It examines, in particular, the veritable boom of associative activity that centered around SABs at the beginning of the I950s and its relationship with local politics. In addition, this study explores connections between neighborhood associations and labor union struggles at the end of the I950s and beginning of the I960s, a period of major political polarization and the affirmation of a language of rights centered around the universe of labor. Based on strong social networks and informal relationships created by workers, ${ }^{1 \circ} \mathrm{I}$ argue that organizations like the Neighborhood Friends Societies were fundamental to the construction of political communities that had a powerful impact on electoral processes and on the formation of the state at the local level. Likewise, this article will show how, during that period, identities at the neighborhood level frequently developed in dialogue with processes of class formation, staking claim to a language of rights associated with the condition of being a worker and, simultaneously, a citizen. Finally, seeking to bring my own research agenda into dialogue with a transnational perspective, this article suggests how analyses with such a localized scope, like those focused on specific working-class neighborhoods, can intervene in debates concerning Global Labor History. Despite the broad recognition of the importance of neighborhoods and residential locales to processes of class formation, the body of research conducted from

8. Jorge Wilheim, Projeto São Paulo. Propostas para a melhoria da vida urbana (Rio de Janeiro, 1982), p. 63.

9. Oliver Mongin, "Metrópole para poucos”, Carta Capital, 27 janeiro 2010, p. 2 I.

Io. A more detailed analysis of the role of social networks and of informal relationships in neighborhood organization and in the labor union movement can be found in my book, Paulo Fontes, Migration and the Making of Industrial São Paulo (Durham, NC, 2016). See also, idem and Francisco Macedo, "Strikes and Pickets in Brazil: Worker Mobilization in the 'Old' and 'New' Unionism, the Strikes of 1957 and I980", International Labor and Working Class History, 83 (2013), pp. 86-I I I. 
a global studies perspective still appears to undervalue the comparative and transnational potential of "local" studies undertaken with a "microanalytical" approach.

\section{NEIGHBORHOOD FRIENDS SOCIETIES AND POLITICAL LIFE IN SÃO PAULO IN THE $1950 \mathrm{~s}^{11}$}

On 29 March I954, Mayor Jânio Quadros's office received a letter with claims made by residents of a far-flung neighborhood in the north zone of the city. The missive was signed by Moacyr Lázaro Barbosa, Mario dos Santos Lourenço, and Magnólia Pires de Souza, respectively the president, council president, and the secretary-general of the Vila Gustavo Friends Society. The typewritten text, written on the Society's letterhead, which indicated that the entity had been founded on 20 June 1948 , requested, "in the name of the approximately I,500 members" of the organization, that the city provide "public illumination on Avenida Júlio Bueno, because this is a main, inter-neighborhood avenue [...] on which the Vila Gustavo buses travel". The authors of this brief letter closed by emphasizing their certainty that the mayor would attend to their "appeal that this Society is making to him", which aimed to "interpret and transmit to the appropriate authorities the anxieties of this forgotten, proletarian population, which, although humble, also contributed to São Paulo's development and its greatness". ${ }^{22}$

Requests such as this one, sent directly to the mayor, were common in those years. Indeed, every day the mayor's office was flooded with letters, messages, petitions, and claims authored by the newly formed and territorialized Neighborhood Friends Societies (Sociedades Amigos de Bairro, $\mathrm{SABs}) .{ }^{\mathrm{I}}$ It is difficult to trace the emergence of the first Neighborhood Friends Societies. Associations with this curious name, however, seem to have first appeared in the late I930s and early i940s, probably inspired by Friends of the City Society (Sociedade de Amigos da Cidade), an organization created in 1934 by engineers, urbanists, and other middle-class professionals (including Francisco Prestes Maia, the city's mayor from 1938 to 1945). These pioneers in shaping an association in São Paulo concerned with the city's development, in turn, seem to be have been inspired and

I I. An earlier, preliminary version of this section was published as part of a larger research project, under the title "Trade Unions, Neighbourhood Associations and Working Class Politics in São Paulo, Brazil (1950s-r960s)", in Sabyasachi Bhattacharya and Rana Behal (eds), The Vernaculization of Labour Politics (New Delhi, 2016), pp. 63-82.

I 2. Processo 064475/1954, DGDP-2, SMPOG. My emphasis. As we will see below, the use of such terms as "proletarians", "laborers", and "workers" was frequent in the petitions and similar documents, as a reference to the public that the Sociedades Amigos de Bairro claimed to represent. I3. Residents' organizations, such as the SABs, would be a fitting subject for analysis with a focus on the participation of women in civil society and political life. Future studies must develop in a more detailed way this fundamental aspect of neighborhood life. 
influenced by the Friends of the City of Buenos Aires Society (Sociedad Amigos de la Ciudad de Buenos Aires) and by the local development associations (Sociedades de Fomento) that proliferated in the neighborhoods of the Argentine capital during that period. ${ }^{\mathrm{I}}$

Yet, it was only during the years immediately following World War II that São Paulo would experience a visible surge in residents' organizations with an expressly local and territorial character. Particularly encouraged and influenced by the then-ascendant Communist Party (Partido Comunista do Brasil - PCB), the neighborhood-based groups quickly spread through working-class areas of the city, under the name of Democratic and Popular Committees (Comitês Democráticos e Populares - CDPs), expressing a wide-ranging set of demands for urban improvements, administrative decentralization, and democratization of urban governance. ${ }^{\text {Is }}$

In the political vacuum brought about by the criminalization of the Brazilian Communist Party in 1947 and the consequent extinction of the $\mathrm{CDPs},{ }^{16}$ some of those previously involved in them as well as other activists reoriented and organized themselves under the name of "Neighborhood Friends Societies". In this same vacuum, Jânio Quadros (I917-I992), ${ }^{17}$ a previously obscure local assemblyman, managed to capitalize on and collaborate with this new civil society movement based in São Paulo's

I 4. On the Argentine influence on the constitution of the SABs in São Paulo, see an interview by Adriano Duarte with former community movement leader Eduardo Rosmaninho, is September 1999. The interview transcript has kindly been made available to me by the historian Adriano Duarte.

I s. For the CDPs in São Paulo, see in particular Adriano Duarte, "Em busca de um lugar no mundo. Movimentos sociais na cidade de São Paulo nas décadas de 1940 e 1950", Estudos Históricos, 2 I:42 (2008), pp. 195-2 19. This phenomenon was also pronounced in Rio de Janeiro. Cf. Marcos César de Oliveira Pinheiro, Os Comitês Populares Democráticos na cidade do Rio de Janeiro (MA, Universidade Federal do Rio de Janeiro, 2007).

I6. Having been legalized only in 1945 , the PCB experienced a period of growth both in numbers and influence, and was banned again in 1947 in the context of the intensification of the Cold War. The communists nonetheless continued their activities in a more or less clandestine manner, depending upon the particular moment, and despite this illegality they would once again exert major influence on organized labor and intellectual and political life between the end of the r950s and the military coup in 1964 .

17. One of the most controversial politicians in Brazilian history, Jânio Quadros, a talented orator with a peculiar style of his own, zigzagged across the political spectrum: If his political career began on the left with the support of the Brazilian Socialist Party (including some Trotskyites) and the more progressive sectors of the Christian-Democrats, Quadros progressively moved to the right of the national political scene. Combining a rhetoric against administrative corruption with his frequent support for workers' demands for urban improvements in the city's poor suburbs, Jânio Quadros had a meteoric and impressive political career. In less than thirteen years, he was successively elected city council member, state congressional representative, mayor, governor, federal congressional representative, and president. His polemical renunciation of the presidency in August I96I, after only seven months in power, marked the beginning of a period of political instability that would be ended by the military coup in 1964 . 
working-class neighborhoods and cultivated an interrelation between these and the city's authorities as no other politician had before.

It was precisely in the context of his mayoral campaign in 1953 that the Neighborhood Friends Societies gained public prominence. The election of Jânio Quadros came as a surprise to the world of traditional politics. Quadros's victory would be called the "Revolution of March 22 "nd" by his allies, in a reference to both the date of the election and to the magnitude of the transformations that he sought. But the electoral triumph revealed, above all, the power of the vast support base he had built, in a relatively short time, through the SABs in São Paulo's working-class neighborhoods. During his exhilarating campaign, Quadros made the neighborhood residents' demands his own, and, receiving 65.8 per cent of the vote, he won an astounding victory, in particular in the city's peripheral districts. From then on, it would no longer be possible to pursue politics in São Paulo without taking seriously the SABs and their claims and demands.

Quadros's victory and the expectations it generated gave the existing SABs a huge boost: By way of mobilizations and claims sent directly to the new leader of the local government, the SABs tried to take advantage of the momentum created to demand improvements for their districts. Apparently, Quadros's victory also accelerated the formation of new residents' associations of this kind. Judging from the dates when these associations were created, found on the logos printed on the correspondence that they sent to the mayor, several of these "Sociedades de Amigos" were founded in the period immediately following the election of the new mayor.

Moreover, in the immediate wake of the election, a major wave of industrial strikes ${ }^{18}$ reinforced the pressures on the new mayor, who had been elected as the "champion of the periphery". Aware of the political potential of these associations and clearly interested in keeping himself close to them, the mayor encouraged the neighborhood associations as they took on a more active role in public life in pursuit of their interests. The mayor's view of the SABs as welcome protagonists in São Paulo's urban politics, becomes clear, for instance, in a petition with more than 6,000 signatures,

I 8. One week after Jânio Quadros's election, an enormous strike paralyzed the city's main industries, as part of a broad protest movement that took over São Paulo for about a month. Known as the "Strike of the 300,000 " the work stoppage was in large measure articulated and organized by the textile, metallurgy, and print industry workers, among others, and was made manifest both in factories and neighborhoods. The strike had a strong impact on the workers' movement in São Paulo and in Brazil generally, giving rise to a new phase in the organizational development and the public presence of unionism. For different interpretations of the Strike of the 300,000, see José Álvaro Moisés, Greve de massa e crise política (estudo da Greve dos 300 mil em São Paulo, I953-54) (São Paulo, I978); Hélio Costa, Em busca da memória (Comissão de fábrica, partido e sindicato no pós-guerra) (São Paulo, I995); Joel Wolfe, Working Women, Working Men: São Paulo and the Rise of Brazil's Industrial Working Class, 1900-1955 (Durham, NC, 1993); and Murilo Leal, A reinvenção da classe trabalhadora (1953-1964) (Campinas, 20I I). 
addressed to Quadros and sent by the Vila Izolina Mazei Friends Society. The residents of this neighborhood, defining themselves as "all poor workers", demanded that a series of improvements be made to the region and reminded the mayor of the speech "solemnly delivered at the Moinho Velho Friends Society, and published in the [newspaper] A Gazeta", in which Quadros had "called upon its residents to formulate their requests concerning public improvements whenever possible, by way of their NEIGHBORHOOD FRIENDS SOCIETIES". ${ }^{9}$

Many requests were sent asking the mayor to serve as an intermediary between neighborhood residents and companies holding concession contracts to provide telephone services (Companhia Brasileira de Telefones) or electrical energy (The São Paulo Light and Power Company, known simply as "Light São Paulo") in order to provide the neighborhoods with a telephone (to be installed, in general, in a local pharmacy or bakery) or with street lighting. These cases, which were dealt with in direct action-style on the part of the secretaries and departments of the mayor's office, were rather opportune occasions on which Quadros could don his hero's cape and apply pressure to utility companies like Light São Paulo, the target of his virulent attacks since his time as a city council member.

In this regard, speed seemed to maintain the mayor's image of a personal relationship with his constituents and his responsiveness to their needs. The directors of the Vila Olimpia Friends Society, for instance, in a letter dated I 2 April I954, requested that the mayor have a public telephone installed in a neighborhood bakery, reminding him that "as Your Excellency has already explained to us verbally, the lower part of the neighborhood has no telephone whatsoever, which makes urgent communications impossible". ${ }^{20}$ Only two days later, Quadros responded to the Society, confirming that he had already placed a request to the company for the telephone line and the telephone itself.

The majority of these requests consisted of pleas to pave the streets, install telephones and public lighting, collect trash, create public markets to supply people with basic foodstuffs, and start or extend bus lines. The range of demands included the installation of a children's playground, a neighborhood daycare center, or the placement of curtains and blinds in a public school in the area. At times, this came with detailed information (including maps) about where these new establishments should, ideally, be located. ${ }^{21}$

Beyond their role in making claims on behalf of and mobilizing residents of the neighborhood, the Friends Societies were also sociable and leisure spaces.

19. Processo 175660/1954, DGDP-2, SMPOG. Capitalization as in original.

20. Processo i $8840 / 1954$, DGDP-2, SMPOG. Emphasis added by author.

2I. Such as those requested by the SAB of the neighborhood Vila Guilherme in the first case and by the SAB of Vila Matilde in the second. Cf. Processos 162258/1954 and I22407/1954, DGDP-2, SMPOG. 


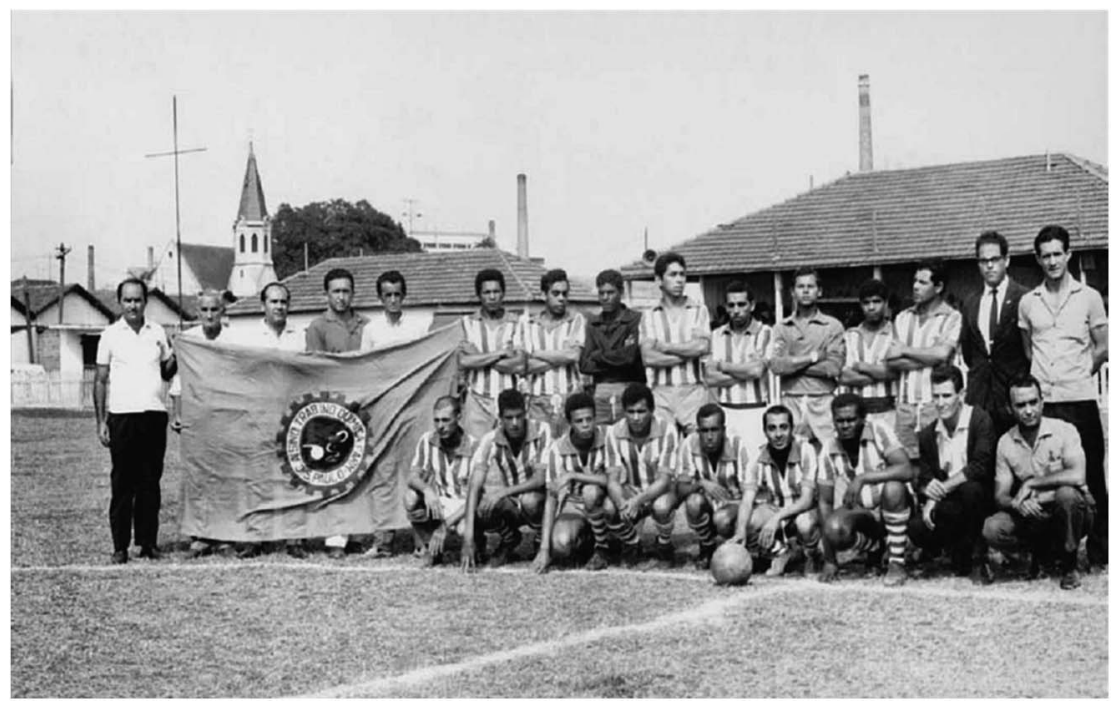

Figure 2. Many SABs were created in connection with amateur football and recreational local clubs in the working class districts of the city.

Library of the São Paulo Chemical Industrial Workers Union. Used by permission.

As several studies show, many of these societies originated in or were associated with local sporting (particularly amateur soccer) and dance clubs and organizations devoted to entertainment in general. ${ }^{22}$ Thus, it should come as no surprise to find amid these many demands for urban improvements a request for a license made by the Tremembé and Zona da Cantareira Friends Society, "to carry out four Carnival balls and two children's matinees, as part of the celebrations during the days of Carnival", in February of $1953 .{ }^{23}$ Other local institutions and organizations also recognized the channels that opened up between the SABs and the municipal authorities and directed their own, particular appeals through neighborhood associations. This was the case, for example, in some local parishes of the Catholic Chuch. In Vila Palmeiras, Egisto Domenicali, the president of the local Friends Society, made a request on behalf of Father Antonio de Fillipo, asking the mayor "to pave the area in front of the parish church [of the neighborhood]". ${ }^{24}$

22. Cf. Adriano Duarte, "Neighborhood Association, Social Movements, and Populism in Brazil, 1945-1953”, Hispanic Historical American Review, 89 (2009), pp. I I I-I 39; Leal, A reinvenção da classe trabalhadora; and Paulo Fontes, "Futebol de Várzea and the Working Class: Amateur Football Clubs in São Paulo, I940s-1960s", in Paulo Fontes and Bernardo Buarque de Holanda (eds), The Country of Football: Politics, Popular Culture, and the Beautiful Game in Brazil (London, 2014), pp. 87-102.

23. Processo $28232 / 1953$, DGDP-2, SMPOG.

24. Processo I $57177 / 1954$, DGDP-2, SMPOG. 
Public works were one of the most common demands, the pavement of roads in particular and construction projects in general. To have the street paved was generally a precondition for demanding further improvements, such as street lighting and public transportation. Again, this had been in part instigated by Jânio Quadros himself, who, as soon as he assumed the position of mayor, launched an "Emergency Plan" for carrying out these improvements, in particular paving the streets.

The language of most of these petitions and other communications directed to the mayor's office was far from begging for a "favor". The tone was, generally, respectful and formal. The gratitude and praise for the mayor pointing to his "high public spirit" and "elevated sense of justice"25 was matched by references to promises made by the mayor during his candidacy or during a visit that he had made to a particular neighborhood. These pieces of correspondence, whenever possible, highlighted the personal contacts that had been previously made with politicians or visits that residents had paid to the offices of government authorities. When asking "Doutor Professor Alípio Correia Netto", Secretary of Hygiene in the Quadros mayoral administration, to install a public market in their neighborhood, for instance, the directors of the Vila Ipojuca Friends Society reminded him that the missive they were sending was simply intended to reinforce "what they had already had the opportunity to report to him in person". ${ }^{26}$

It was, however, through the use of the language of labor that the neighborhood residents represented in the SABs most insistently claimed their rights before the mayor. The authors of most of these petitions and letters mentioned repeatedly that theirs was a "working-class neighborhood", and phrasings such as "the large numbers of workers, men and women", living in Vila Independência in Ipiranga were not limited to this particular SAB. In a similar vein, the SAB of Vila Gumercindo emphasized that the neighborhood was made up of a "hard-working population of over ten thousand inhabitants", while the residents of Vila D. Pedro II called themselves "humble laborers", but ones who wanted "justice". ${ }^{27}$ The examples are many and recur frequently in the documents. The world of labor had, admittedly, already been valorized by the state for some time - the reference to labor and its association with citizenship rights had been a central characteristic of Getúlio Vargas's government in the I930s and I940s (even if this was often only a rhetorical gesture). This continued and took on an even more complex and expansive dimension in the relatively democratic post-war period, when various political forces began

25. See, respectively, processos I60804/1954 and i $8840 / 1954$, DGDP-2, SMPOG.

26. Processo I04888/1954, DGDP-2, SMPOG.

27. See, respectively, processos I 29598/I954, I I 8840/1954, and I39256/I954, DGDP-2, SMPOG. 
to court workers. It is thus unsurprising that, under these circumstances, many workers (especially industrial workers), intensified their struggles for rights, tying these struggles to an identity and a language of class. ${ }^{28}$ What is more remarkable, however, is how this identification was also embraced by a significant number of residents of poor neighborhoods, who underscored their condition as workers to express their demands for improved urban infrastructure and their part in the "progress" of the city. It was as workers, and not simply as individuals living in São Paulo, that an increasing number of residents demanded their rights to the city.

Jânio Quadros's connections with the SABs were decisive for structuring a reliable, well-oiled political machine that the future president could count on for many years. Several of the presidents and directors of the Friends' Societies remained ardent Quadros supporters, and some even built their own political careers. At the local level, the manifold claims and demands of neighborhood residents had established a stable channel of communication with the state, and, for neighborhood associations, this implied growing participation in urban politics. The capillary nature of the SABs' relations and connections thus increasingly became an object of desire for politicians across São Paulo’s entire ideological spectrum. City Council members, in particular, whose electoral survival depended on securing a strong base in the neighborhoods, sought to establish their own privileged relationships with SABs and often tried to outdo each other in vocalizing and directing their demands to the executive authority.

Thus, from the mid-I950s on, it was not only Jânio Quadros and his followers that fought for representation in working-class neighborhoods by way of the SABs. The residents' associations were probably the most politically pluralistic social movement of that era. If, on the one hand, a class identity could be and was typically claimed by the "Friends Societies" (and could only be appealed to by those who shared it, or claimed to share it as well); on the other hand, a neighborhood identity, another central characteristic of the association, was more open and easily addressed and adopted by politicians of different stripes.

A considerable proportion of the existing studies of the political relationships between poor residents and political leaderships in cities going through accelerated urbanization processes have tended to characterize such relationships as clientelistic, based purely on the logic of the "exchange of material benefits for votes". ${ }^{29}$ Thus, organizations like SABs functioned

28. There is an immense literature on this subject. Important examples include Wanderley Guilherme dos Santos, Cidadania e justiça. A política social na ordem brasileira (Rio de Janeiro, 1979); John D. French, The Brazilian Workers' ABC: Class Conflict and Alliances in Modern São Paulo (Chapel Hill, NC, I992); and Alexandre Fortes et al., Na luta por Direitos. Estudos recentes em História Social do Trabalbo (Campinas, 1999).

29. Studies in this vein exist, of course, for the whole of Latin America (and indeed for other world regions). Typical representatives in the Brazilian context include José Álvaro Moisés, 
only as institutional mediators for the political schemes of clientelistic networks. According to this reasoning, the SABs would be a prototypical example of the populist logic of manipulation and cooptation. An important conclusion of this type of approach is a presumed fragility of civic culture and the absence of a tradition of autonomous organization of civil society in Brazil (and, one can say, in Latin America in general), this being a central element in the country's lack of citizenship and democracy. In this type of analysis, however, the language and the actions of the Neighborhood Friends Societies and their constituents is typically neglected and subordinated to the logic of the state and its political leadership. Moreover, these studies seem to suggest a structural dichotomy between clientelistic networks and social mobilization. In contrast, the analytical efforts undertaken in this article aim to emphasize the perspective of the SABs and the agency of their participants. It is thus possible to understand how, in certain contexts, a language of rights associated with a discourse of class could be articulated and made binding even within a logic of domination and action that can be called clientelistic. Furthermore, following the trails blazed by such authors as Charles Tilly and Javier Ayero, neighborhood associations in São Paulo seem to confirm that "patronage and contentious politics can be mutually imbricated". ${ }^{\circ}$ As we shall see in the following, the SABs' debates about decentralization and municipal autonomy and the approximation of neighborhood organizations with the labor unions and strike movements can offer interesting examples in this regard, as they point to attempts to develop other forms of action that were able to adapt to new constellations.

\section{NEIGHBORHOODS, DECENTRALIZATION, AUTONOMY}

Jânio Quadros only remained in the position of São Paulo's mayor for about two years, swiftly moving on to be the state's governor (I955-I 959). While the principal constellation of considerable interaction between neighborhood associations and the city government continued under his successors, it is not surprising that the intense dynamic of the initial years soon wore off, not least because the city continued to expand and, with that, the number of new neighborhoods and urban challenges. In this situation,

Classes populares e protesto urbano (São Paulo, 1978); and Maria da Glória Gohn, Movimentos sociais e lutas pela moradia (São Paulo, I99I). A similar analytical scheme can be found in the more recent approaches of James Holston, Insurgent Citizenship: Disjunctions of Democracy and Modernity in Brazil (Princeton, NJ, 2008); and Leonardo Avritzer, A participação política em São Paulo (São Paulo, 2004).

30. Javier Auyero, "Poor People's Lives and Politics: The Things a Political Ethnographer Knows (and Doesn't Know) After Fifteen Years of Fieldwork”, New Perspectives on Turkey, 46 (2012), pp. 95-107, 106. See also Charles Tilly, Regimes and Repertoires (Chicago, IL, 2006); and Javier Auyero, Poor People's Politics (Durham, NC, 2000). 
a new orientation emerged among numerous neighborhood activists, one that no longer sought closer collaboration with the existing authorities but, on the contrary, a move away from them. In the course of the I950s and the beginning of the I960s, a series of movements calling for the administrative separation of working-class neighborhoods arose in various places in the São Paulo metropolitan region. These movements consisted of several actors; yet, in many cases, as we shall see, SABs played a central role in them. Basically, these movements demanded the separation of neighborhoods and entire regions from the administrative control of the city of São Paulo and their transformation into autonomous municipalities, each with its own budget. ${ }^{3 \mathrm{I}}$ These movements shared the idea that their areas had been the victims of abandonment and forgetting, and that only with administrative emancipation through a secession from São Paulo would it be possible to bring local power into line with the population's real necessities, especially in the poorest districts. The perception of a powerful injustice in the distribution of public resources on the part of the mayor's office, which benefitted the city's wealthiest, central neighborhoods to the detriment of the underprivileged periphery, was another common characteristic of the defenders of autonomy. ${ }^{32}$

For a district to call for political and administrative separation, it was necessary to fulfill several requirements stipulated in the federal Constitution of 1946 and to carry out a plebiscite, which needed to be authorized by the State Legislative Assembly. Even when autonomy was approved by a majority of local voters, however, strong political and juridical resistance from municipal mayor's offices confronted with such secessionist aspirations remained common, trying to prevent the territorial dismembering of their cities and the consequent loss of a population of constituents and of economic resources. Thus, the success of the processes of autonomy depended on a large and permanent popular mobilization, demanding both the build-up of political pressure as well as effective and proficient legal counseling.

This was the case with Osasco, probably the most famous and successful example of an autonomous district having seceded from the municipality of São Paulo. After its defeat in a first plebiscite carried out in 1953, the local

3I. In the period being analyzed here, the Brazilian federalist system was composed of three government levels: federal, state, and municipal. Thus, administrative autonomy of a municipality implied the constitution of executive power (composed of an elected mayor and vice-mayor) and a local parliament (composed of elected city council members), in addition to its own budget. As mentioned before, "districts" or "neighborhoods" were (often quite informal) administrative subdivisions with no legal or budgetary consequence.

32. The social struggles for municipal autonomy in São Paulo are another topic of potential interest for comparative study. In many large cities in different countries, workers' districts in the areas surrounding the city and its suburbs have called for precisely the opposite, in other words for these areas' incorporation into the municipality. 
autonomists reorganized themselves and managed to conquer the majority of votes when polling took place again in 1958. The São Paulo mayor's office appealed the voters' decision, followed by a long legal and political battle that inspired an impressive popular mobilization in the region. Osasco finally separated from the capital, becoming an autonomous city in I 962, when the newly formed municipality elected a mayor and city council members for the first time. ${ }^{33}$

Estimates indicate that, between 1945 and 1964, seventeen peripheral neighborhoods attempted to separate from São Paulo. Invariably, the attempts and campaigns for autonomy involved the local SAB. In reinforcing the elements of a local, communitarian identity, these campaigns also highlighted all of the dissatisfaction with the precarious conditions in working-class neighborhoods. At the same time, the campaigns clearly demonstrated a building pressure to extend democracy to the local level and a popular mobilization for citizenship. This went beyond the realm of labor and union organizing, with urban poverty serving as an important concern and reference point for the consolidation of the struggle for rights.

Legal and political difficulties, however, frustrated most of these attempts. But other arguments also influenced the results of some of the plebiscites in the few locales where they did take place: For instance, in an initial attempt at separation undertaken by the populous neighborhood of São Miguel, in the extreme east of the city, the worst damage to popular support for the campaign for autonomy were caused by rumors that a future city of São Miguel would be considered part of the state's hinterland, rather than an urban area and, as such, the salary index in force in this municipality would be held to a different standard from the capital city and other regions of the state and thus would be lowered. In contrast, the autonomists, trying to counter the arguments of the "No" campaign and, in particular, the salary question, demonstrated, for example, that in São Caetano do Sul (autonomous since the I940s) the wages remained the same. What is remarkable about this dispute, however, is that both to defenders and opponents of separation the relevance of this labor-related issue seemed evident. Arguments directed at the residents as workers in this respect were broadly brought to bear on the campaigns, both pro and against autonomy.

At any rate, in the early I960s, autonomist struggles in numerous neighborhoods resurfaced with great force, stimulated by the victory of the highly industrialized district of Osasco, which was officially made into an independent municipality in 1962. The vigorous mobilization and the victory of the autonomists in that locale served as an example of the possibility of secession and gave a strong stimulus to those that similarly argued 
in favor of the emancipation of their neighborhoods in various parts of the São Paulo metropolitan area. In addition, the new mayor of Osasco, Hirant Sanazar, as well as several city council members from the recently created municipality, gave their explicit support to the various autonomist movements in the capital of the state of São Paulo. Present at an autonomist rally in São Miguel in June of 1963 , for example, Sanazar attacked those who opposed secession and reminded the gathered crowd, "four years ago the São Paulo stepmother did nothing for Osasco, only taking care of the elegant neighborhoods", and, after enumerating a series of urban improvements in the newly autonomous municipality, like asphalted streets, health services, and urban cleaning services, he concluded, in a grandiloquent and messianic tone, that "autonomy means redemption". ${ }^{34}$

Beyond the uplifting example of Osasco, autonomy and the accompanying debate concerning administrative decentralization and the resolution of the urban problems that afflicted the residents of São Paulo's working-class neighborhoods appeared to be directly related to the general mood favoring change and mobilization, brought about by the proposals of the so-called Basic Reforms Plan (Reformas de Base). This wide-ranging set of demands, which not only included measures for land, tax, educational, and constitutional reform, but also proposals for a decentralization and democratization of urban areas, were advanced during the presidential administration of João Goulart (196I-1964), a left nationalist who enjoyed considerable support from the labor movement. It is no coincidence, then, that in the early i960s many labor unions and leaders became actively involved in movements for autonomy in neighborhoods in São Paulo.

The military coup in 1964 put a stop to all of the mobilizations and initiatives for neighborhood autonomy in São Paulo. With the road to actual autonomy blocked, many turned their attention once more to the mayor's office, building up pressure (to the degree possible under dictatorship) for administrative decentralization as a way of attending, however partially, to the demands of peripheral neighborhoods. In fact, a decision, in 1965, by Faria Lima, the incumbent mayor, to create so-called Regional Administrations in many neighborhoods, sub-entities with the partial powers of a proper mayoralty, appears to have been a direct response to the

34. Cited from a report of the Department of Political and Social Order (Departamento Estadual de Ordem Política e Social - DEOPS), the organ of São Paulo's police in charge of the surveillance and investigation of all kinds of political and social movements and whose documentation offers unique (though, of course, very partial) glimpses of the activities of movements that have otherwise left few archival traces. DEOPS documentation gathers not only police papers and reports, but also an immense variety of original and unique sources from individuals, political parties, trade unions, and social movements apprehended by the police from the mid-r920s to the early r980s. Dossiê 50-Z-59I, fls. 64, Arquivo Público do Estado de São Paulo [hereafter, APESP], Departamento Estadual de Ordem Política e Social [hereafter, DEOPS]. 
mobilization of neighborhood entities and of the autonomist movement that had grown in São Paulo in the years just prior to the military coup. In the years to come, the SABs, which had not been proscribed by the military dictatorship, would come to play a fundamental role in urban politics. Although the political conditions were much more adverse than in the previous years, the socio-economic conditions of the neighborhoods compelled the SABs and other actors to continue their mobilizations and struggles. Consequently, the SABs increasingly went beyond the specific claims made by each neighborhood, and began to put the administration of the city as a whole and the role of the local government on their agenda.

\section{SABs, LABOR UNIONS, AND STRIKES (1957-1964)}

At the end of the I950s and the beginning of the r960s, in the context of growing social tensions and political struggles, workers were generally able to expand their space in the Brazilian public sphere. This was mainly true for (male) industrial workers in the cities and increasingly for rural workers in the countryside, but, as the example of the neighborhood associations illustrates, also included other groups of workers and the broader urban population. A nationalist, anti-imperialist rhetoric was powerfully articulated with a language of class that clamored for more inclusive economic development and deep social reforms in Brazil. Such political currents as the leftist nationalists and communists grew in the political scene. An overall picture that featured growing inflation, a wave of strikes, and protests characterized a period of intense political and social polarization that would come to a close with the military coup of 1964 .

In that period, neighborhood organizations in São Paulo lived through a rapid process of radicalization and significant changes in the forms of action and political alliances in which they engaged. The year 1957 appears to have been a moment of particular importance for these changes. The SABs umbrella organization - the Federation of São Paulo Neighborhood Friends Societies (Federação das Sociedades Amigos de Bairros and Vilas de São Paulo, or FESAB), which had been created in $1954,{ }^{35}$ became stronger and began to act more consistently in conjunction with various other associations. For instance, in July of that year, a convention of SABs in São Paulo was organized, sponsored by the FESAB. Besides highlighting the accomplishments of the SABs so far, "in the sense of having achieved improvements in the general, immediate, or local order, such as: transportation, housing supply, water, illumination, sewage, pavement, mail delivery, telephone, public health, instruction, sports, etc.", the convention demanded the right of these entities to participate in the "master plan of the city [...] and in the administration of the CMTC [Companhia Municipal de Transportes - Municipal 
Transportation Company]" and the formation of a "São Paulo metropolitan consumers" cooperative" to ameliorate the problems of furnishing the city with basic supplies. ${ }^{36}$

At the about the same time, the unions in São Paulo appear to have become increasingly attentive to the needs for workers beyond the shop floor and the need to organize workers in their neighborhoods. In a booming city like São Paulo, union leaders became ever more sensitive to the demands for urban improvements and increasingly sought strategies that accounted for urban geography. In the second half of the I950s, various local unions, such as those of the chemical and metal workers, founded sub-headquarters in new neighborhoods with large concentrations of workers, as a way to bring unions closer to the laborers' residences and, thus, to facilitate activism and worker participation in the running of these organizations.

At that juncture, one could also perceive a tightening of the bonds between neighborhood associations and the labor union movement. This was illustrated, for instance, by the presence of the former in a meeting called by the Inter-Union Unity Pact (Pacto de Unidade Intersindical, or PUI $)^{37}$ to debate the growing cost of living in São Paulo. ${ }^{38}$ Joint actions not only began to occur more frequently, but these two movements also started to articulate a common agenda of demands. The subjects of their claims for urban improvements slowly penetrated the union agenda and some union members began to participate more actively in neighborhood organizations. This was the case, for example, for Santos Bobadilha, a well-known leader of the Union of Dairy Workers of São Paulo, who, in those years, became an active militant in the Jardim São Vicente Friends Society.

The so-called Strike of the 400,000, carried out in October of 1957 , represents an important moment for the strengthening of the ties of unity between these organizations. It also brought about the emergence of a shared language and agenda between unions and neighborhood

36. These quotations are from FESAB convention documents cited in a secret police report, Dossiê $50-\mathrm{J}-\mathrm{I} 38$, fls. I45, APESP, DEOPS.

37. The Inter-Union Unity Pact (PUI) was created in 1953 , bringing together the majority of the more militant trade unions in São Paulo. An alliance was consolidated between trade union leaders connected to the Communist Party (PCB), which was then illegal, but very active in the factories and neighborhoods, and trade unionists tied to the Brazilian Labor Party (PTB), which had Vargas-linked origins, but increasingly identified with the figure of Vice-President João Goulart. Equally significant was the political presence of labor leaders without ties to those parties or who were allied with other politicians, as in the case of the governor of São Paulo, Jânio Quadros (1955-1959). In addition to the defense of the workers' interests, it was a nationalist and antiimperialist discourse that held this broad alliance together.

38. See the following report by US-American consul, an external but sensitively interested observer: Despatch I69 of February I, I 957 from Amcongen, São Paulo, Brazil. Subject: Cost of Living meeting of São Paulo Labor, National Archives and Records Administration, Archives II (College Park, MD), General Records of the Department of State (GRDS), RG 59, Central Foreign Police Files (CFPF), LAB 3-3, Box 4308, Document 83201/2-2037. 


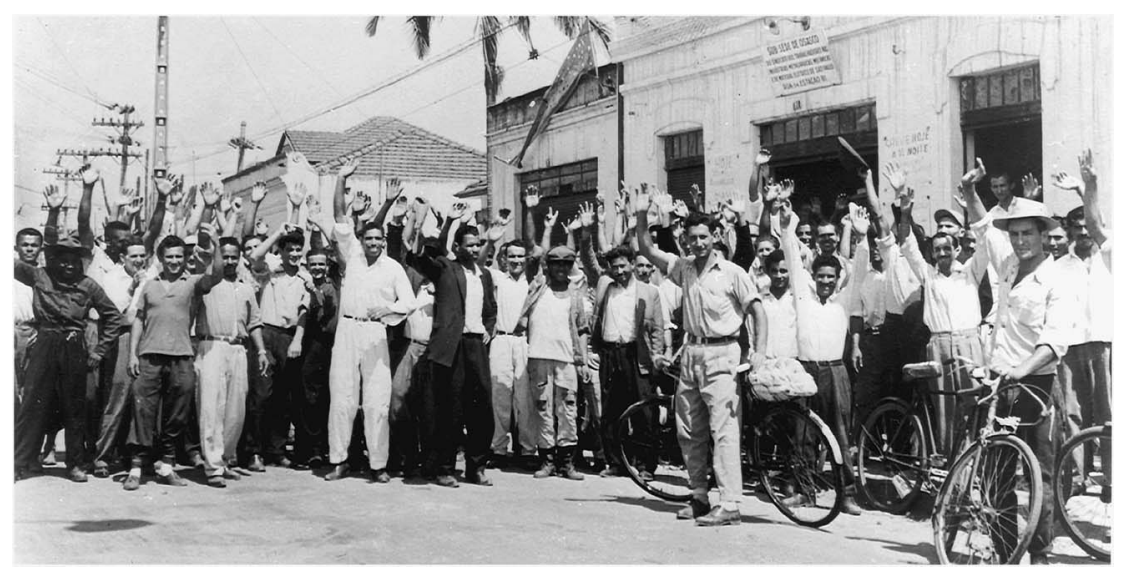

Figure 3. The so-called Strike of the 400,000 in 1957 was an important moment for the strengthening of the ties of unity between the SABs and trade-unions. Many picket lines were organized in the neighborhoods.

Arquivo Público do Estado de São Paulo. Fundo Última Hora. Used by permission.

associations, which conceived workers also as residents of the city, and vice versa. Organized by a network of unions from various trades and industries, in particular the textile and metal industries, the strike, which took place at a moment when the economic plight of the poorer classes had caused widespread dissatisfaction, soon became a generalized labor action that paralyzed the whole city of São Paulo and other neighboring industrial cities. The movements took on the air of a popular rebellion: Picketing strikers took over the streets and several violent confrontations occurred in what is one of the most remarkable episodes in the labor history of São Paulo. ${ }^{39}$ During this strike, the neighborhoods were one of the main locales that provided assistance for and sustained the work stoppage. Many picket lines, for instance, were organized in meetings convened in clubs and in residents' organizations in the industrial districts. In the months leading up to the strike, many SABs positioned themselves in defense of workers' rights and thus in favor of the unions' position against the high cost of living. In the middle of the October strike, the alliance forged among residents' associations and the union organizations of the city would be powerfully confirmed when FESAB released a manifesto expressing solidarity with workers, arguing that the "SABs are constituted in their absolute majority by workers from all industries and professions [...] and the struggle for a reduction in the cost of living is inherent in all of the people". ${ }^{\circ}$

39. For more details about this strike, see, among others, Paulo Fontes and Francisco Macedo, Strikes and Pickets in Brazil; and Leal, A reinvenção da classe trabalhadora, ch. 6. 40. Dossiê 50-J-138, fls. I 26 and I93, APESP, DEOPS. 
The approximation between neighborhood-based movements and labor unions continued in the following years. In June 1958 , a new meeting of FESAB, which already included 196 popular associations that had joined together, debated such old demands as the paving of streets in the urban periphery, but they also discussed the "formation of a common front of action, between the [neighborhood] entities, the Interunion Unity Pact, and the State Union of Students [União Estadual dos Estudantes]". ${ }^{\mathrm{I}}$ Neighborhood problems and the demands of city dwellers were, in turn, increasingly discussed by union organizations, as in a meeting of the union of bank workers, in which union leaders and the SABs debated "the project of the city council member Norberto Mayer Filho concerning renewing the contract" of the Brazilian Telephone Company (Companhia Telefônica Brasileira).${ }^{42}$ Subjects like the problems of food supplies and cooperativism took an important place on the agendas of PUI meetings. ${ }^{43}$

The spike in the cost of living was one of the main topics that united the neighborhood associations and unions. At the end of the I950s, these entities jointly organized various protests against inflation, the loss of purchasing power as a result of low wages, and the ensuing impoverishment. In June 1959, for example, the labor attaché of the British Consulate reported on the preparations for a "hunger march" that would bring a caravan of "unionists, students, and members of neighborhood associations" to Rio de Janeiro (then still the national capital). ${ }^{44}$ This growth of FESAB and of the neighborhood movement in São Paulo as well as their alliance with the unions worried the authorities to such a degree that, when the entity actively participated in the organization of a strike movement in December, the Ministry of Justice authored a law closing down the FESAB and other SABs for ninety days, although it was never put into effect. ${ }^{45}$

In the effervescent period before the coup of 1964, the contacts and connections between neighborhood associations and unions appear to have deepened further. The importance of a kind of urban planning that was favorable to workers and poor urban residents in general began to take a more serious and important place on the union agenda. In July i963, for example, some of the city's main unions, like the bank, metal, and textile workers, signed a manifesto calling for urban reform as an important part of the "Basic Reforms Plan" proposed by the João Goulart administration.

41. Última Hora, i6 June I958.

42. Dossiê 50- J-I 38 , pasta I, APESP, DEOPS.

43. On the activities of the union movement concerning food supplies, cooperativism, and struggles against scarcity in the 1950s, see Leal, A reinvenção da classe trabalhadora, particularly ch. 4 .

44. The National Archives [of the UK] (Kew), Foreign Office, São Paulo Consulate, Brazil, Correspondences, FO 371/139125.

45. Dossiê 50-J-I 38 , fls. 323 , APESP, DEOPS. 
The overlapping interests between unionists, architects, and neighborhood organizations resulted in a seminar on the subject of housing and urban reform, which gathered a range of important actors from São Paulo's civil society. The questions of housing, the problems that neighborhoods suffered, and the very question of urban planning as a whole came to be seen by unions as a part of the world of labor. ${ }^{46}$ The coup that took place in April I964, evidently, dealt a death blow to these incipient initiatives. Subsequent attempts to match interests or coordinate activities now had to take place under the conditions of dictatorship.

The experiences of the SABs and of São Paulo's unions at the end of the I950s and the beginning of the I960s demonstrate a far greater political connection between the world of labor and urban questions than the older social science literature has generally recognized. For instance, in 1973, the sociologists Fernando Henrique Cardoso (later to become Brazil's president), Cândido Procópio Ferreira, and Lúcio Kowaric emphasized that, in the I950s and I960s,

as a rule, the workers were absent from political life, at the level of urban demands. $[\ldots]$ The unions did not have the habit of [...] including in their programs questions connected to the urban problematic [...]. [At the same time], one cannot affirm that the Neighborhood Friends Societies represented workers. They represented much more the urban resident, a specific social category that the city created and whose action, during the process during which São Paulo became a major metropolis, attenuated if not completely dissolving class behavior.

Thus, the authors concluded, "the majority of the inhabitants of São Paulo remained politically marginal to municipal life". José Álvaro Moisés, for his part, also considered that, "for a long time", unions never demonstrated any interest "in the demands for urban living conditions for their members". ${ }^{7}$ Yet, as this article has shown, workers' organizations and neighborhood organizations managed, at various moments, to unify their claims, transcending in practice the boundaries between the struggles in factories and in neighborhoods. In this process, a form of political action based on a much broader notion of class emerged, which included various dimensions of the lives of workers in São Paulo, in fact often overcoming the supposed division between worker and resident.

\section{CONCLUSION}

While the nexus between labor and urban issues has often not been fully acknowledged in a certain kind of sociological literature (in particular in the

46. On the seminar and the role of urban planning issues among São Paulo unionists at the time, see Leal, $A$ reinvenção da classe trabalhadora, pp. I 86-1 87.

47. Fernando Henrique Cardoso et al., Cultura e participação na cidade de São Paulo (São Paulo, I973), pp. I 2 and I 3 ; and Moisés, Classes populares e protesto urbano, p. I 82. 
case of big metropoles in the Global South), labor historians have been more observant in highlighting the important role of working-class neighborhoods in the process of class formation during different periods and in various national contexts (though, here too, the focus has been on experiences in the Global North). In particular, in the context of large cities propelled by industrialization from the nineteenth century on, many have underscored the dense sociability of working-class districts as fundamental to the mitigation of multiple social divides and the construction of a class identity, as well as its role in generating support for collective action. In a famous article, Eric Hobsbawm, for example, called attention to the labor movement's difficulties in large cities, "which are industrially very heterogeneous to have a unity based on labour" and "too broad to form true communities". The "communitarian potential" of working-class neighborhoods, however, transcended this "inhospitable environment", for it was here where "the true force of the working-class movement in megalopolises" resided. ${ }^{8}{ }^{8}$ Geoff Eley also reminds us that

workers of whatever kind led lives beyond the workplace [...]. They lived in neighborhoods, residential concentrations, and forms of communities, cheek by jowl with other types of workers and alongside other social groups as well. [...] They came from diverse regions and birthplaces, spoke different languages or dialects, and bore profoundly different cultural identities from religious upbringing and national origins. They were young people and mature adults, and of course women and men.

Thus, "the rise of the urban working-class neighborhood", Eley argues, "was crucial" to the construction of a common working-class identity in Europe between the mid-nineteenth century and the beginning of the twentieth. ${ }^{49}$

To emphasize the roles of neighborhoods in processes of class formation implies a more serious consideration of both the spatial dimension and of constructions of different senses of community in historical analysis. In this respect, the British sociologist Mike Savage points out, in considering the centrality of what he calls "structural insecurity" in the working-class experience, "it is as important to look at the coping strategies used in urban neighborhoods and within households as at the labour process itself". ${ }^{\circ}$

While the mentioned authors have offered valuable clues for understanding the interconnection between neighborhood communities, the workplace, and class identity, there also numerous accounts, especially in

48. Eric Hobsbawm, "Labour in the Great City", New Left Review, I: I66 (1987), pp. 39-5 I. 49. Geoff Eley, Forging Democracy: The History of the Left in Europe, I850-2000 (Oxford, 2002), pp. 57-58.

50. Mike Savage, "Class and Labour History", in Lex Heerma van Voss and Marcel van der Linden (eds), Class and Other Identities: Gender, Religion and Ethnicity in the Writing of European Labour History (New York, 2002), pp. 55-72, 61. 
older or "classical" studies of class formation, that lack attention to these spatial dimensions. This absence was polemically highlighted in Roger V. Gould's revisionist analysis of the famous Paris Commune of i 87i. Gould asserts that the insurrection, contrary to the sacred mythology of the left, had little to do with class struggle and rather concerned the formation of communitarian urban identities in the context of the ongoing disputes over municipal freedoms, as opposed to the political centralization of France in the Second Empire. ${ }^{\text {I }}$ David Harvey has refuted in minute detail both Gould's historical research methodology and the conclusions he draws, emphasizing how, in a variety of historical contexts (such as in the case of the Paris Commune) "there were class identifications related to local places, neighborhoods, and even communities [...]. The signs of class and class consciousness are as important in the space in which people lived as they are in people's work". Thus, Harvey continues, neighborhood institutions are spaces of social solidarity that are perfectly compatible and linked with social relations of class. In the context of the urban transformations of Haussmann's Paris, the city had "a community of class as well as a class of comunity" in Paris's working-class neighborhoods. ${ }^{52}$

Nonetheless, despite the intense debates and the evident weight of the mentioned discussions around working-class districts and their connections to class and communitarian identities, the international literature on these topics is very "parochial", exhibiting an evident lack of transnational or even comparative studies of neighborhoods. Conversely, the burgeoning field of Global Labor History - which precisely calls for an inclusion of such perspectives - conspicuously lacks sensitivity for the spatiality of the local. There seems to be little space for "place" in these more recent approaches, with few studies of local organizations or neighborhood workers' associations realized under their auspices.

One can outline some reasons for this absence. First, a significant part of Global Labor History appears to privilege a return to macro-narratives with an emphasis on economic processes on a global scale, with little interest in highly local studies, such as those at the neighborhood level. Second, a seeming lack of connections and transnationality between neighborhood associations confines their study to a level that, even within the municipal universe, can be considered "micro", making a more global analysis of the phenomenon difficult or, indeed, impossible. Third, although Global Labor History also has broadened our understanding in both time and space of what labor constitutes and who workers are - going decidedly beyond the forms of wage labor predominant in the Northern

51. Roger Gould, Insurgents Identities: Class, Community and Protest in Paris from 1848 to the Commune (Chicago, IL, I995).

52. David Harvey, Paris, Capital of Modernity (London, 2003), particularly ch. I 3. 
Atlantic world from the nineteenth century on - one can still perceive the continuation of the old dichotomy and hierarchy between productive space and the spaces of social reproduction. The role that residential spaces and workers' neighborhoods have played in global development of labor is still underestimated.

Meanwhile, neighborhood associations have, since the I970s, constituted one of the central concerns in studies about the so-called new social movements. Heavily influenced by such authors as Jürgen Habermas, Alain Touraine, and Manuel Castells, among others, a large part of the academic work on this topic has almost entirely fallen to geographers, sociologists, and political scientists emphasizing the "newness" of movements emerging in the I970s. Beyond the supposedly shared values across these movements autonomy vis-à-vis the state and the traditional political forces (including the labor movement), democratic, and participatory internal organization, etc. this "newness" was said to manifest itself also in the emergence of social identities with little or no relation to class identities or with the world of labor. Such views have contributed to a segregation of research fields, with the study of neighborhoods and of territorialized popular organizations remaining largely outside the domain of labor history.

Yet, the study of neighborhood associations in Brazil and in Latin America in general holds many promises for labor historiography, including for studies inspired by the ideas of Global Labor History. Two interesting examples might illustrate the potential for comparative and transnational analysis in the study of neighborhoods and local workers' organizations.

The historiography of India, for instance, has been vigorously questioning the conventional notion that sees factories as spaces of change and modernity and neighborhoods as places of tradition and stasis, in particular those areas that are connected to their rural places of origin, to religion, and to caste. Numerous studies have been demonstrating how urban life at the neighborhood level, associated with the experience of places of work, continually redefined the rules of inclusion and exclusion established between the workers themselves. Neighborhoods also created feelings of belonging and emotional bonds, lending visibility to the workers and to a certain idea of common identity beyond traditional divisions. Workers' connections to their residential locales created the conditions for the emergence of leaderships and local organizations that demanded improvements for their districts and often forged links with union politics. ${ }^{33}$ As one can see, despite great differences in culture and historical context, there are 
interesting confluences in the construction of identities, the formation of organizations, and the making of collective action that unite the cases of neighborhoods in industrial cities in India and in Brazil. Research that takes into account the analysis of working-class neighborhoods beyond the local and the national has much to gain from understanding the processes and unexpected connections, even across long distances, particularly in countries that have gone through rapid and intense processes of urbanization, migration, and industrialization.

As previously stated, the great, industrialized urban centers of Latin America open up another and even more obvious possibility for comparative and transnational analyses, although labor historians have yet to tap adequately into this potential. ${ }^{54}$ The example of Argentina is especially illustrative here. Just as in Brazil, a new generation of Argentine historians has recently been revisiting and adding new questions to the debate about urban popular associations in their county, particularly during the period during the rule of President Juan Perón (I 946-1955).55 A significant part of this literature contradicts the conventional vision, established in the I980s, which saw the strong tendency to form associations at the neighborhood level in Buenos Aires in the I930s (with the proliferation of neighborhood clubs, popular libraries, and sociedades de fomento ${ }^{56}$ ) as an expression of the supposed fact that the lower classes had outgrown primordial organizational forms based on class and ethnicity, which predominated in Buenos Aires until the 1920s. For this reason, these scholars avoided the use of the

54. Despite renewed interest among Latin American historians in the study of associative life and the political potential of working-class neighborhoods, there are still few initiatives that seek to analyze these phenomena from a regional and transnational perspective. For some interesting examples of recent studies of Latin American neighborhoods, see Alejandro Velasco, Barrio Rising: Urban Popular Politics and the Making of Modern Venezuela (Berkeley, CA, 20 I s); Paulo Drinot, "Moralidad, moda y sexualidad. El contexto moral de la creación del barrio rojo de Lima", in Scarlett O'Phelan and Margarita Zegarra (eds), Mujeres, Familia y Sociedad en la Historia de América Latina, siglos XVIII-XXI (Lima, 2006), pp. 333-354; Kenneth Maffitt, "From the Ashes of the Poet Kings: Exodus, Identity Formation, and the New Politics of Place in Mexico City's Industrial Suburbs, 1948-1975", International Labor and Working Class History, 64 (2003), pp. 74-90.

55. For some different perspectives, cf., among others, Omar Acha, "Sociedad civil y sociedad política durante el primer peronismo”, Desarrollo Econômico, 44:174 (2004), pp. 199-230; Rosa Aboy, Viviendas para el pueblo. Espacio urbano y sociabilidad en el barrio Los Perales, 1946-1955 (Buenos Aires, 2005); Anahi Ballent, Las huellas de la política. Vivienda, ciudad, peronismo en Buenos Aires, 1943-1955 (Buenos Aires, 2005); Hernán Camarero, "Consideraciones sobre la historia social de la Argentina urbana en las décadas de 1920 e 1930. Classe obrera y sectores populares", Nuevo Topo. Revista de Historia y Pensamiento Crítico, 4 (2007), pp. 35-60; and Omar Acha and Nicolás Quiroga, Associaciones y política en la Argentina del siglo veinte. Entre prácticas y expectativas (Buenos Aires, 2015).

56. Sociedades de Fomento were residents' associations based on the territory of a neighborhood and began to proliferate in Buenos Aires and in other cities in Argentina from the I920s on. They filled a role that was similar to Brazil's Sociedades Amigos de Bairro. 
notion of "workers" and consecrated the term "popular sectors" for the subaltern residents of Argentina's capital. Implicit in these authors' analysis was the idea that the political culture of the Perón era, from the I940s, with its emphasis on the use of the plebiscite, on state power, and with its tendency to articulate a certain language of class, has put an end to this prior civic culture and destroyed its popular associations as spaces where citizens would experience and experiment with democratic processes. ${ }^{57}$ Contrary to such views, numerous historians have, especially in the last fifteen years, rejected the radical separation between civil society and the state that is implicit in the vision outlined above, and have shown how the Peronist state opened up space for the articulation and re-articulation of various popular demands.

The case of São Paulo in the I950s and I960s equally suggests that the phenomenon of urban associations has played an important role in the construction of a language of rights and in workers' political interaction with local authorities and with the municipality - and that this happened in a more complex manner than analyses emphasizing clientelistic logics have acknowledged. Examining this phenomenon allows us to observe a greater permeability and porosity of the state, which functioned as a site of conflicts and, under certain circumstances, was receptive to the demands from below, as was the case between the I940s and the I960s in Brazil. As this article has explained, a popular, neighborhood identity, on the one hand, and a laborer's, working-class identity, on the other, are not mutually exclusive. Despite their socio-occupational heterogeneity, many neighborhoods in São Paulo recognized themselves and were recognized by others as "working-class". "Popular", "working-class", and "resident" can be complementary identities and are not necessarily in conflict with each other.

57. The fundamental reference from this perspective is the book by Luis Alberto Romero and Leandro Gutiérrez, Sectores populares, cultura y política. Buenos Aires en la entreguerra (Buenos Aires, 1995). More recent reflection on this topic have been produced by Luis Alberto Romero and Luciano de Privitellio, "Organizaciones de la sociedad civil, tradiciones cívicas y cultura política democrática. El caso de Buenos Aires, 1912-1976”, Revista de Historia, I (2005), pp. I-34. Luciano de Privitellio, Vecinos y Ciudadanos. Política y sociedade em la Buenos Aires de entreguerras (Buenos Aires, 2003). 